\title{
"NUNCA FUI, MAS ME DISSERAM" - GEOGRAFIAS IMAGINATIVAS SOBRE A BAIXADA FLUMINENSE A PARTIR DO OLHAR DOS MORADORES DA ZONA SUL CARIOCA
}

\author{
"I NEVER WAS, BUT THEY TOLD ME" - IMAGINATIVE GEOGRAPHIES ABOUT THE BAIXADA FLUMINENSE FROM THE \\ LOOK OF THE PEOPLE OF THE SOUTH CARIOCA AREA
}

\section{RESUMO}

O presente artigo ambiciona um diálogo com o documentário "Nunca fui, mas me disseram..." no tocante a discussão geográfica suscitada pela obra. Produzido em 2007 pelo estúdio Meigueto+1 de forma independente e experimental, o documentário em questão apresenta relatos de moradores de bairros da Zona Sul carioca sobre a Baixada Fluminense. As opiniões desses moradores aparecem impregnadas de estereótipos devido ao fato de muitos não conhecerem empiricamente a outra região. Dessa forma, passados dez anos da produção do documentário, procuramos expor as visões distorcidas presentes no discurso dos moradores da Zona sul do Rio de Janeiro a partir de uma reflexão de natureza geográfica. A análise dessa situação aponta para um desconhecimento da Baixada Fluminense em razão da não necessidade de recorrer aos serviços dessa área da Região Metropolitana por parte dos moradores da região carioca e, também por conta disso, a "geografia imaginativa" referente à Baixada Fluminense ser consideravelmente construída pela mídia, a qual recorre, sabidamente, a sensacionalismo para retratar essa região.

Palavras-chave: Baixada Fluminense. Zona Sul Carioca. Geografias Imaginativas.

\section{ABSTRACT}

This article aims at a dialogue with the documentary "Never was, but I was told ..." regarding the geographical discussion raised by the production. Produced in 2007 by the Meigueto +1 studio in an independent and experimental way, the documentary in question presents reports of residents of neighborhoods in the Southern Zone of Rio de Janeiro over the Baixada Fluminense. The opinions of these residents appear impregnated with stereotypes due to the fact that many do not empirically know the other region. Thus, ten years after the production of the documentary, we tried to expose the distorted visions present in the discourse of the residents of the South Zone of Rio de Janeiro from a reflection of a geographical nature. The analysis of this situation points to a lack of knowledge of the Baixada Fluminense due to the lack of need to resort to the services of this area of the Metropolitan Region by the inhabitants of the region of Rio de Janeiro, and also because of this, the "imaginative geography" referring to the Baixada Fluminense is considerably constructed by the media, which, sensibly, uses sensationalism to portray this region.

Keywords: Baixada Fluminense. South Zone Carioca. Imaginative Geographies.
Enderson Alceu Alves Albuquerque a

${ }^{a}$ Universidade do Estado do Rio de Janeiro (UERJ), Rio de Janeiro, RJ, Brasil

DOI: $10.12957 /$ geouerj.2020.30714

Correpondência:

endersonalbuquerque@yahoo.com.br

Recebido em: 6 out. 2017

Revisado em: 6 set. 2019

Aceito em: 20 mar. 2020 


\section{INTRODUÇÃO}

A distância entre o município de Nilópolis, localizado na Baixada Fluminense (BF) onde reside o autor deste artigo e o bairro de Copacabana, símbolo emblemático da cidade do Rio de Janeiro localizado na Zona Sul (ZS), é de apenas $45 \mathrm{~km}$. A distância é superada em cerca de 50 minutos de automóvel por moradores da Baixada Fluminense quando é preciso consumir produtos e serviços não existentes na periferia da metrópole fluminense. Contudo, se na direção do túnel André Rebouças para a Zona Sul os moradores da Baixada Fluminense necessitam de menos de uma hora para concluir o itinerário, e como as necessidades mais imediatas dos habitantes da Zona Sul são suprimidas com o setor terciário local, o percurso inverso parece ser infinitamente maior. A distância socioeconômica acaba por superdimensionar a distância geográfica entre as distintas regiões.

Devido a essas distâncias física e simbólica, o imaginário referente à Baixada Fluminense para os moradores da ZS carioca é mediado, em grande medida, pela mídia e pela opinião de outras pessoas. Dessa maneira, essas opiniões são escassas de empirismo e se alicerçam em "achismos" dos mais variados. Quando perguntados sobre a origem das opiniões sobre a Baixada Fluminense, na maioria das vezes, a classe média e alta carioca da ZS responde: "Nunca fui, mas me disseram", título do documentário com o qual dialogaremos ${ }^{1}$.

Conforme preconiza sua sinopse, o documentário aborda estereótipos espaciais "mas sem a pretensão de responder ou esclarecer algo, apenas discutir a origem do estigma". Com efeito, a produção cinematográfica apenas incita um debate e, dessa forma, não pretende ultrapassar as visões estereotipadas sobre a Baixada Fluminense. Nesta perspectiva, de complementar a discussão suscitada pelo documentário, o artigo em questão se insere e se justifica. Debater a falta de comunicação entre essas duas partes de uma mesma Região Metropolitana, na qual o fluxo de residentes ocorre, de maneira mais intensa, em apenas um sentido, é, também, um dos objetivos deste artigo, o qual ambiciona apontar os equívocos referentes à Baixada Fluminense expressos nas falas dos entrevistados.

Cumpre ainda registrar as dificuldades de se trabalhar com escalas distintas como bairros e município. Os dados referentes aos municípios expressam a realidade média das pessoas considerando as distinções espaciais compreendidas em seu interior, porém, não conseguem captar as sutilezas da dinâmica dos lugares. Ao produzirem números generalistas sobre um determinado espaço, tendem a produzir homogeneizações que escamoteiam as verdadeiras distinções sociais internas.

Os dados construídos em escala municipal ao extrair uma média local e estender tais valores como representativo de todo território, desvirtua, consequentemente, o entendimento dos extremos sociais. Já os dados relacionados aos bairros refutam a realidade média municipal expressando com maior fidelidade a

${ }^{1}$ Disponível em https://www.youtube.com/watch?v=E8sUcveY6XA 
realidade socioespacial daquele recorte e assim tendem a apresentar maior coesão social em seu interior. Por essa razão, optamos em não comparar diretamente os dados dos bairros da cidade do Rio de Janeiro com os municípios baixadianos

Estruturamos o artigo em três partes. Na primeira procuramos contextualizar a Baixada Fluminense enquanto na segunda parte discutiremos a realidade socioeconômica da Zona Sul da Cidade do Rio de Janeiro. Alicerçada sobre o conceito de "geografia imaginativa", a terceira parte do artigo se presta a um diálogo com o documentário supracitado. Nosso intuito é problematizar as visões dos moradores entrevistados objetivando uma revisão sobre a Baixada Fluminense que supere o imaginário coletivo. O recorte temporal para essa análise compreende 2007, ano de produção do documentário até o de 2017, ano de elaboração do artigo.

Da acepção geomorfológica a concepção socioeconômica: delimitando a Baixada Fluminense

Refletindo sobre as intervenções realizadas pelo governo de Nilo Peçanha entre os anos de 1909 e 1910, Lago (2000, p. 67) assinala que essas

\begin{abstract}
obras de saneamento e drenagem executadas na Baixada Fluminense nesse período, em vez de impulsionar a produção agrícola para o abastecimento da cidade, abriram novas fronteiras para a expansão imobiliária. Surgia nesse momento um novo padrão de produção do espaço construído urbano, os chamados "loteamentos periféricos", que mudaria, doravante, a forma e o conteúdo não apenas do Rio de Janeiro, mas das demais grandes cidades brasileiras.
\end{abstract}

A alteração da forma e conteúdo aludida por Lago se manifestou através do adensamento demográfico dos municípios vizinhos ao Rio de Janeiro. Por consequência, houve a expansão da mancha urbana, até então limitada à cidade do Rio de Janeiro. No contexto fluminense tal processo se materializou juridicamente com a criação da Região Metropolitana do Rio de Janeiro em 1973.

A área metropolitana fluminense nasceu formada por dois estatutos jurídicos distintos, o do Estado da Guanabara e o do Estado do Rio de Janeiro. Havia um notório descompasso socioeconômico entre o núcleo da região metropolitana e seu entorno, como reforça Santos (2002, p. 13) ao dizer "que separada administrativamente do seu entorno, o núcleo da região metropolitana não financiou a implantação da infraestrutura adequada para atrair investimentos industriais para a Baixada Fluminense".

Nesse contexto, de uma área metropolitana altamente concentradora, a Baixada Fluminense se inscreve como integrante de sua periferia (RIBEIRO \& O'NEILL, 2012). Essa região, por sua vez, não encontra consenso entre os pesquisadores no tocante a seus limites territoriais. Dependendo do critério utilizado, o limite territorial e o número de municípios podem se expandir ou retrair. Referente ao debate acadêmico, Oliveira (2004) nos apresenta três noções distintas das dimensões territoriais da baixada fluminense. 
A primeira, pautada em critérios geomorfológicos, foi elaborada entre as décadas de 1930 (GÓES, 1934) e 1960 (GEIGER \& SANTOS, 1955). Enquanto o primeiro se atém às características hidrográficas para estabelecer sua delimitação, os outros dois autores consideraram a "relação existente entre a sociedade e o espaço natural, dando ênfase às relações econômicas que predominavam em determinadas localidades" (MAGALHÃES, et al., 2013, p. 13) para erigir sua delimitação.

No entanto, a concepção de Baixada Fluminense extrapola a acepção meramente geomorfológica. Nesse sentido, conforme defende Oliveira (2004, p. 24), "o aspecto natural passou a ser associado com os elementos políticos, sociais e econômicos, apresentando construções distintas das verificadas acima". Afinados às proposições de Oliveira (2004), a segunda noção, engendrada por Beloch (1986), considera apenas os municípios com estreitas ligações com o município do Rio de Janeiro - caso de Nova Iguaçu, Duque de Caxias, Nilópolis e São João de Meriti-, como sendo pertencentes à Baixada Fluminense. A terceira conceituação, estabelecida pela Secretaria de Desenvolvimento da Baixada e Região Metropolitana (SEDEBREM), considera treze municípios pertencentes a essa região, como indica o mapa abaixo (Figura 1). Essa delimitação territorial será a considerada para a estruturação desse trabalho.

Figura 1. Municípios componentes da Baixada Fluminense. Fonte: ROCHA, 2015

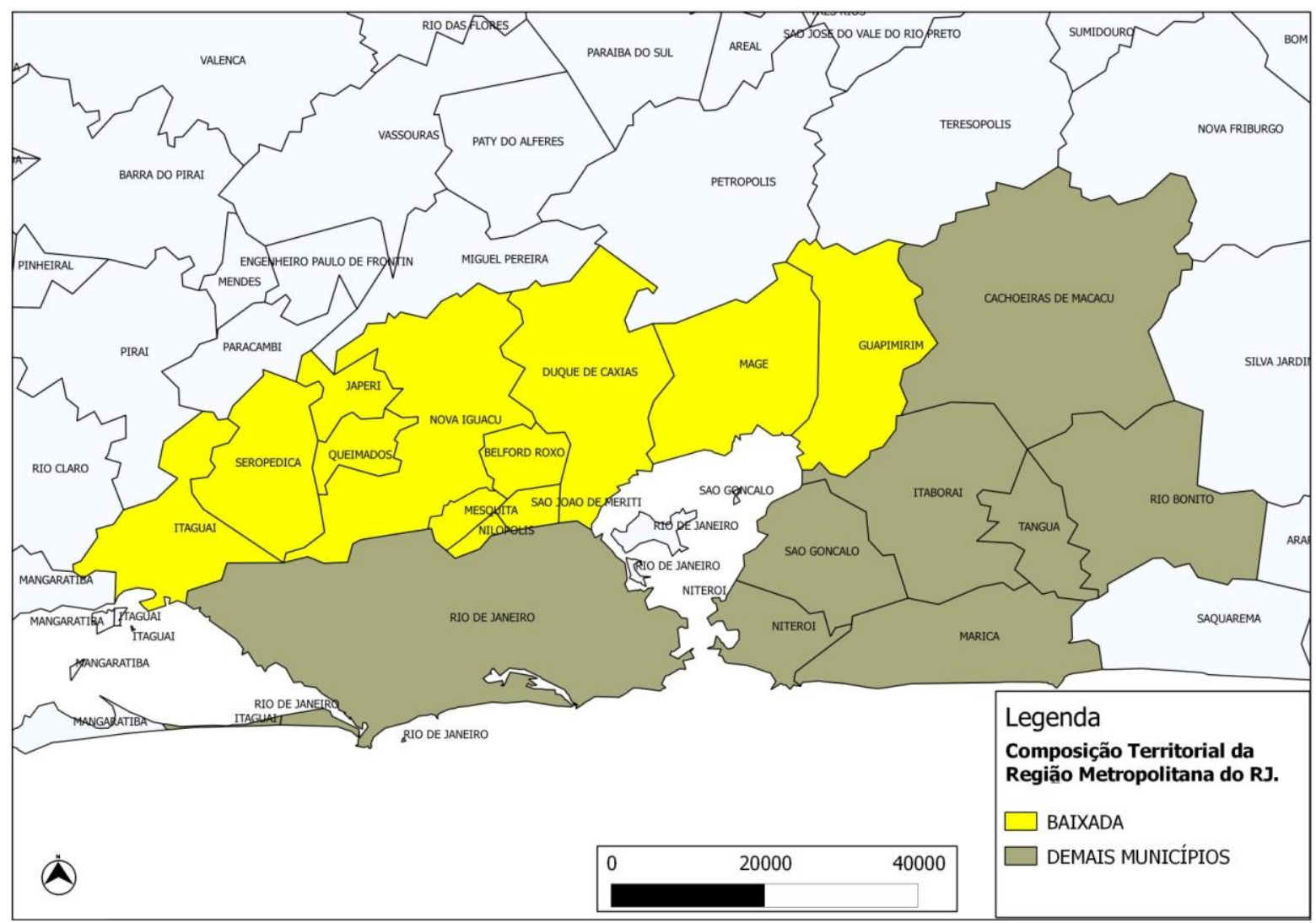

Desse modo, a primeira conceituação se atém as características naturais para delimitação da região, enquanto as demais se utilizam dos critérios socioeconômicos. Entre os trabalhos empreendidos para 
delimitar os limites físicos da Baixada Fluminense merecem destaque ainda os de Segada Soares (1962) e Souza (2014). A primeira autora pelo seu trabalho clássico sobre o processo de ocupação da Baixada Fluminense e a segunda pela revisão dos trabalhos referentes à região.

A caracterização da região ao oscilar de acordo com os critérios adotados, como exposto, entre outros por Gomes (2010), abre a possibilidade de distintas delimitações de Baixada Fluminense tendo como referências aspectos naturais ou socioeconômicos. Por conta disso, a delimitação de Baixada Fluminense apresenta limites nem sempre consensuais entre os pesquisadores que a tiveram como centro de suas reflexões. Simões $(2008$, p. 21$)$ ressalta que

\begin{abstract}
não existe um consenso geral do que seja a Baixada Fluminense, quais os seus limites e os municípios que a compõe. A cada trabalho sobre essa região reabre-se o debate, pois cada autor se coloca de maneira diferenciada com relação a área a ser delimitada. Contudo, existem alguns consensos que devem ser ressaltados. Os municípios de Nova Iguaçu e Duque de Caxias são apontados, com unanimidade, como núcleos desta região, assim como não há questionamento sobre a inclusão de seus "satélites" imediatos, como Belford Roxo, São João de Meriti, Nilópolis, Mesquita, Queimados e Japeri, que são incluídos como parte da Baixada Fluminense por todos os autores, mas nem sempre analisados com a mesma profundidade que o "núcleo duro". Os problemas se encontram nos limites leste, oeste e norte. Dependendo dos autores, Magé e Guapimirim podem ser ou não inseridos na Baixada Fluminense, o mesmo ocorrendo com Itaguaí, Seropédica e Paracambi.
\end{abstract}

Independentemente da ausência de consenso referente à delimitação territorial da região e suas respectivas controvérsias, o recorte adotado foi associado à violência por muito tempo. Essa associação é fortemente consolidada no imaginário fluminense. Alves (2003, p. 15), por exemplo, relata o fato de uma deputada federal, que ao tomar conhecimento da chacina ocorrida no dia 30/08/1993 na favela de Vigário Geral, lamentou a tragédia ocorrida "naquela favela da Baixada Fluminense". A parlamentar, em seu depoimento, associa a favela de Vigário (como é denominada popularmente) à Baixada Fluminense de forma errônea. Essa declaração demonstra a associação direta estabelecida no imaginário entre violência e Baixada Fluminense. Contudo, o documentário em tela expõe a permanência dessa visão ultrapassada sobre esse recorte espacial por parte de moradores da Zona Sul carioca. Desse modo, a parte seguinte deste artigo analisa a realidade socioeconômica dessa região carioca como forma de delimitar o nosso segundo recorte territorial.

Da especulação imobiliária aos cartões postais: Delimitando a Zona Sul carioca

A ZS carioca é composta pelos bairros Catete, Cosme Velho, Laranjeiras, Flamengo, Botafogo, Urca, Humaitá, Leme, Copacabana, Ipanema, Leblon, Lagoa, Jardim Botânico, Gávea, São Conrado, Vidigal e Rocinha (Figura 2). Esses 17 bairros somam 633.393 residentes de acordo com o Censo Demográfico de 2010 corresponde a cerca de $10 \%$ da população total da cidade do Rio de Janeiro. Contudo, o processo de ocupação populacional da região ocorreu de maneira mais intensa somente no decorrer do século XX. 
Figura 2. Bairros da Zona Sul carioca. Fonte: www.encontrenorio.com.br

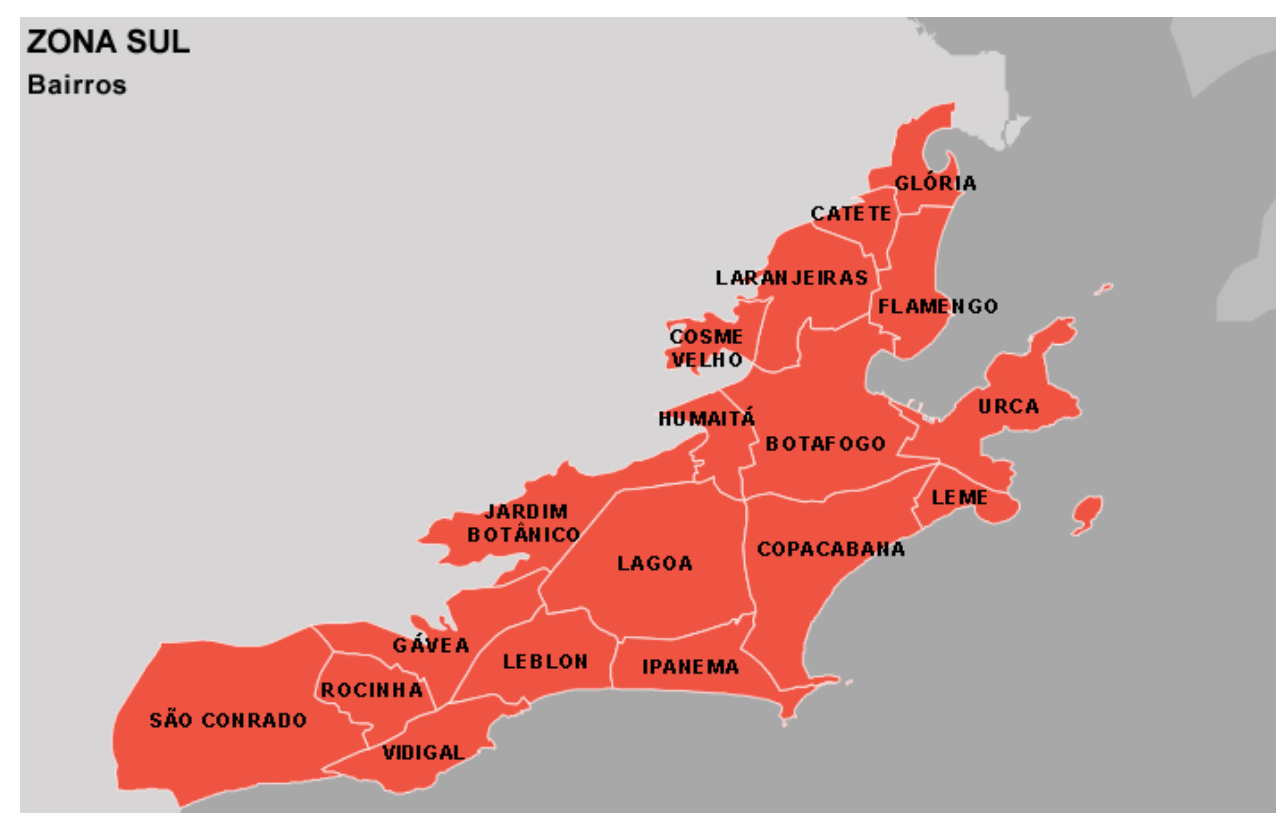

A expansão da cidade do Rio de Janeiro em direção a sua área atlântica esteve, também, vinculada ao movimento de "modernização" da então capital do país. Em razão de seu papel como capital da república, a cidade do Rio de Janeiro necessitava ser uma vitrine do Brasil para o mundo e, nesse sentido, era preciso construir um discurso no qual a cidade entrava na era da modernidade, era "civilizada". Optando por essa premissa, as intervenções urbanísticas desse período apresentaram como característica a dimensão estética da cidade, o sistema de belas artes. A preocupação central residia nas transformações de natureza mais "cosméticas" da cidade através de planos de embelezamento. Essa geração impunha uma primazia das características higiênico-sanitárias de forte influência francesa, de acordo com Pires (2010).

Em virtude de sua preocupação estética, o urbanismo sanitarista não considerava a dimensão social da cidade em um contexto mais amplo. A cidade do Rio de Janeiro é emblemática desse descaso social com as reformas de Pereira Passos a partir do ano de 1903. Em prol de um modelo de cidade mais harmônico, para atender as aspirações da elite de criar uma cidade de padrão europeu nos trópicos, essa reforma expulsou a população de menor status social do centro da cidade.

Coadunando a essa dimensão pretendida da cidade, "o discurso higienista e civilizatório encontrava respaldo nos usos e projetos destinados àquela região da cidade [zona sul], que não era vista como o avesso do progresso, mas como o grau zero, ou seja, o lugar fértil para o desenvolvimento dos projetos de progresso e civilidade" (COSTA, 2014, p. 151). Com efeito, embora bairros como Botafogo, Flamengo, Catete e Glória já haviam sido ocupados anteriormente (CARDOSO, 2004), a abertura de túneis e a criação das linhas de bondes, favoreceu o adensamento populacional da região, com destaque para Copacabana, datada no início do século XIX, a qual nasceu como símbolo de status social. 
Para que a ZS despontasse como lugar "civilizado" da cidade, tão importante quanto à criação material do espaço por meio de infraestrutura, foi sua produção simbólica por meio da elaboração de discurso sólido minuciosamente tecido pelos atores envolvidos. Dessa maneira, de acordo com Cardoso (2004, p. 8),

para que se originasse um novo processo de segregação residencial, foi necessário o surgimento de novos símbolos atribuídos às diferentes áreas da cidade. De um lado, a palavra subúrbio deixou de significar "os arredores da cidade" para ser atribuída aos locais de moradia de classes médias e pouco abastadas, que teriam sido ocupadas pelos trens e que se situavam ao norte da cidade. De outro, surgiu o conceito/símbolo de "zona sul", referido à área da cidade composta pelos bairros que eram banhados pelo mar, que abrigavam as classes médias e altas da população, as quais tinham um estilo de vida moderno e sofisticado. Além destes dois termos passarem a ser utilizados como verdadeiros "topônimos", surgiria também outro, o de "zona norte", identificado com os bairros da cidade habitados por classes médias, distantes do mar e que teriam um "estilo de vida" conservador.

Essa estratégia alterou significativamente a configuração simbólica da cidade, pois "a ocupação dos bairros atlânticos fez com que pouco a pouco a imagem da cidade se dissociasse do passado vinculado às sociabilidades do centro [...] e se deslocasse crescentemente em direção à zona sul e à cultura da vida praiana" (COSTA, 2014, p.154). Nesse sentido, a "invenção da Zona Sul", termo cunhado por Cardoso (2004), esteve fortemente amparada à construção simbólica desse espaço como lócus de população civilizada, moderna, sofisticada. Em outras palavras, como a cidade é parte de uma mercadoria e que, em razão dessa dimensão ela é vendida, a construção de um espaço dito civilizado pretendeu elevar o preço da terra e limitar seu acesso a população de menor poder aquisitivo. Dessa maneira, a zona sul carioca já nasce vinculada a população de elevado status social, já surge socioespacialmente segregada.

Os dados do Censo Demográfico do IBGE de 2010 apontam a característica elitista dessa região da cidade no período atual. O município do Rio de Janeiro é composto por 161 bairros. Entre os 10 bairros cariocas de melhor Índice de Desenvolvimento Humano, 8 estão na Zona Sul. Considerando os 10 bairros de maior esperança de vida ao nascer, 9 são bairros dessa zona com destaque para a Gávea na qual esse indicador ultrapassa os 80 anos. Entre aqueles de maior longevidade, 8 são bairros sulistas - os indicadores expostos aparecem expressos na tabela 1 , a seguir.

Tabela 1. Dados socioeconômicos dos bairros da Zona Sul considerando sua posição na cidade do Rio de Janeiro. Fontes: Censo Demográfico de 2010, IPP e Armazém de Dados

\begin{tabular}{cccc}
\hline Bairros & População & IDH & Colocação \\
\hline Gávea & 17475 & 0,970 & 1 o \\
Leblon & 46670 & 0,967 & 2o \\
Ipanema & 46808 & 0,962 & 50 \\
Lagoa & 18675 & 0,959 & 6 o \\
Flamengo & 53268 & 0,959 & 70 \\
Humaitá & 15186 & 0,959 & 9 o \\
Laranjeiras & 46381 & 0,957 & 10 o \\
Jardim Botânico & 19560 & 0,957 & 11 o
\end{tabular}




\begin{tabular}{cccc}
\hline Bairros & População & IDH & Colocação \\
\hline Leme & 14157 & 0,955 & $12^{\circ}$ \\
Botafogo & 78259 & 0,952 & 13 o \\
Urca & 6750 & 0,952 & 13 o \\
Catete & 21724 & 0,901 & 260 \\
Cosme Velho & 7229 & 0,878 & 340 \\
São Conrado & 11155 & 0,873 & 38 o \\
Vidigal & 13719 & 0,873 & 38 o \\
Rocinha & 69356 & 0,732 & 120 o \\
\hline
\end{tabular}

A ZS historicamente apresenta população de elevada renda. Com efeito, os serviços sediados em seus bairros apresentam melhor qualificação para atender a demanda dessa classe mais abastada. Em razão do elevado status social e do fato de ter suas demandas de consumo saciadas em grande medida em um raio curto pelo fato de alguns bairros da Zona Sul se configurem como subcentros espontâneos nos quais os serviços prestados variam desde os vinculados ao cotidiano até aos mais sofisticados ligados aos tratamentos médicos, por exemplo, os moradores dessa área não necessitam "consumir" o espaço da Baixada Fluminense, com raras exceções. Em virtude dessa questão, o imaginário relativo aos municípios baixadianos e parte dos bairros limítrofes das Zonas Norte e Oeste, são eivados de distorções, conforme aborda o documentário em tela. Debater essas visões distorcidas erigindo um contraponto baseado em dados científicos e analíticos constitui o escopo da parte seguinte deste artigo.

Geografias imaginativas, preconceitos reais: a Baixada Fluminense pela ótica da Zona Sul

As geografias imaginativas, de acordo com Driver (2005, p.144), são "representações de lugares que estruturam o entendimento de mundo das pessoas e consequentemente ajudam a moldar suas ações". Sob tal perspectiva, o entendimento de um determinado espaço passa, também, pela construção simbólica que as pessoas fazem desse lugar. Esse entendimento, por sua vez, é amplamente construído a partir do discurso e das imagens associado ao lugar e reforçado pela mídia. Assim, discurso e imagem são categorias necessárias para se entender a geografia imaginativa referente à Baixada Fluminense.

Para Foucault (1996, p. 10-11), “o discurso não é simplesmente aquilo que traduz as lutas ou os sistemas de dominação, mais aquilo, por que, pelo que se luta, poder do qual podemos nos apoderar, permitir a transubstanciação e fazer do pão um corpo". A ideia do filósofo francês aponta para a força do discurso em sua capacidade de legitimação. Essa legitimação é tecida por indivíduos e, sobretudo, por inúmeras instituições entre elas a mídia, o governo e a igreja- daí "fazer do pão um corpo". Sobre essa discussão, Bourdier (1996) advoga que o poder não reside na palavra em si, mas na legitimidade daquele que produz o discurso, pois não basta construir um discurso apenas. A legitimação é sempre relacional em razão de ela necessitar de aceitação pela parte daqueles que a ouve, lê ou observa- como no caso de imagens. 
A matéria prima da produção de um discurso é as palavras, contudo, as imagens também corroboram com esse intento, especialmente nos meios midiáticos. Questionamos com mais frequência o que ouvimos ou lemos, mas nem sempre nos permitimos ponderar sobre aquilo que vemos. A imagem é comumente convertida em signo de verdade para nossa sociedade. Aquilo que não se vê parece não existir, como nos lembra Moran (2009). Devido a sua condição de portadora da verdade e ao fascínio exercido por ela nas gerações atuais, a imagem é amplamente adotada na mídia. Entretanto, as imagens não se sobrepõem às palavras, elas se complementam. As imagens impactam, mas são as palavras que as confirmam ou as questionam, pois, conforme expõe Santos (2012, p.18), "descrição e explicação são inseparáveis".

Desse modo, a geografia imaginativa referente à Baixada Fluminense, é fruto de um discurso que se materializa e se reforça com o uso de imagens nos meios midiáticos. A figura 3 revela parte dessa construção seletiva de imagens. Pesquisa na internet feita por meio do site de busca Google em 31/08/2017, na opção "imagens", reforça os estereótipos das regiões selecionadas. Na pesquisa relativa à Zona Sul aparece imagens de cartões postais como o Cristo Redentor e as belezas naturais dessa porção carioca como o relevo, as praias e a baía da Guanabara.

Na pesquisa sobre a Baixada Fluminense (Figura 4) aparecem imagens de rio sem canalização, enchentes, população em momento de lazer, elevado adensamento populacional em desacordo com as normas urbanísticas e ainda uma junção de imagens referentes à citada região sob o lema "As belezas da Baixada Fluminense". Nesse sentido, a ZS é apresentada visualmente como um espaço de paisagem harmônica, cênica, enquanto a BF é veiculada a partir de sua carência urbanística e de infraestrutura.

Figura 3. Imagens relacionadas à Zona Sul em pesquisa na internet. Fonte: google.com.br

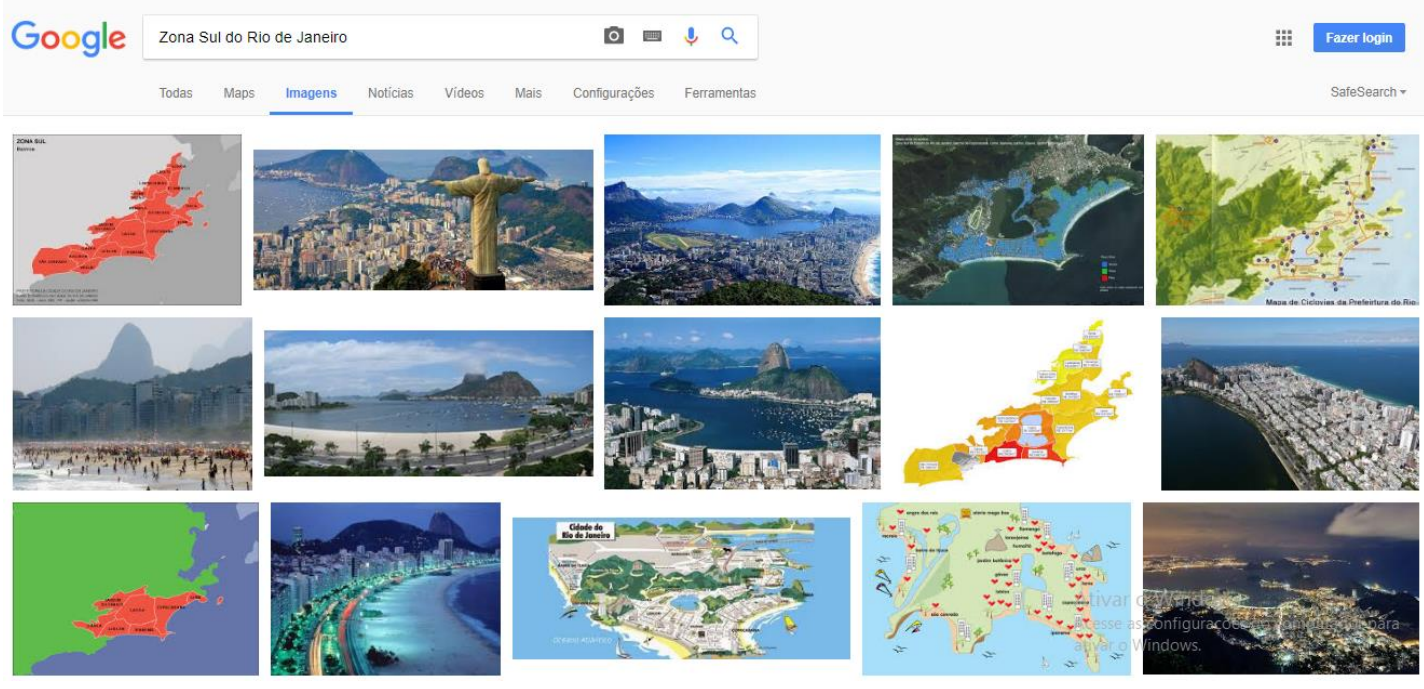


Figura 4. Imagens relacionadas à Baixada Fluminense em pesquisa na internet. Fonte: google.com.br

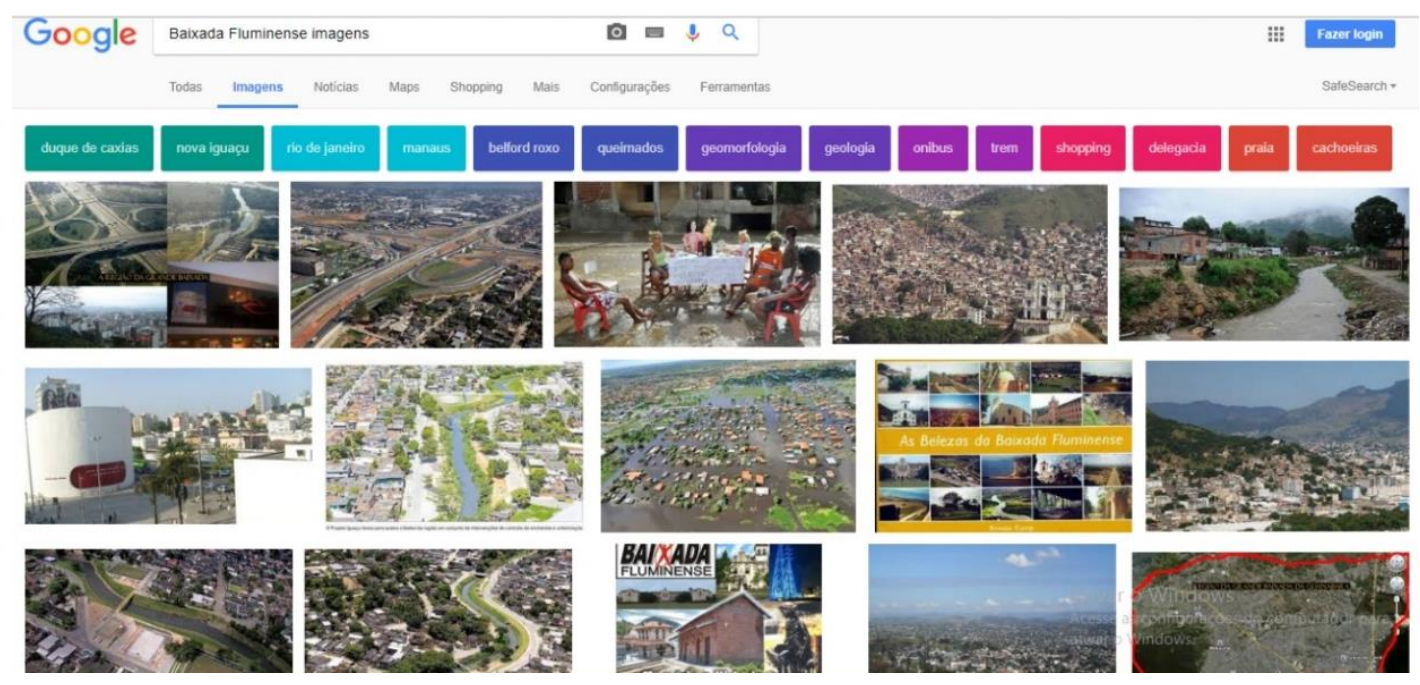

Dessa forma, além da produção de um discurso equivocado, a construção referente à Baixada Fluminense é construída e/ou reforçada, também, por meio da produção da imagem. As imagens, por sua vez, possuem um poder singular de comunicação. Na esteira desse pensamento poderíamos afirmar que uma imagem diz mais que mil palavras? Para uma sociedade caracterizada pela pressa, que lhe rouba o tempo de uma análise mais profunda, a imagem pode até dizer mais que mil palavras; porém, para o ambiente acadêmico, exigente de um olhar mais crítico, essa afirmação suscita algumas ponderações necessárias a respeito de sua validade.

A máxima em questão não nega a importância da palavra, apenas aponta a capacidade de síntese da imagem. E como toda síntese, a imagem é fruto de seleção, a qual, consequentemente, precisa de um seletor, que por sua vez apresenta interesses revestidos de uma determinada ideologia. Nesse sentido, Moraes (1996, p. 21), nos lembra sobre a necessidade da "relatividade histórica", nos advertindo a respeito do perigo de "dissociar o produtor, o produzido e o contexto de sua produção". Dessa forma, sustentamos que a imagem pode incorrer em equívocos, tanto quanto as palavras costumeiramente incorrem, conforme aponta Joly (2007, p. 9-10) quando expõe que

\begin{abstract}
a opinião mais comum sobre as características de nossa época, já repetida há mais de trinta anos, é que vivemos em uma 'civilização da imagem'. No entanto, quanto mais essa constatação se afirma, mais parece pesar ameaçadoramente sobre nossos destinos. Quanto mais vemos imagens, mais corremos o risco de ser enganados e, contudo, só estamos na alvorada de uma geração de imagens virtuais, essas 'novas' imagens que nos propõem mundos ilusórios e, no entanto, perceptíveis, dentro dos quais poderemos nos deslocar sem por isso ter de sair de nosso quarto.
\end{abstract}

O discurso referente à Baixada Fluminense é reforçado pelas imagens a ela associada e são produzidos em grande medida por agentes externos. Com efeito, esses discursos estão eivados de geografia imaginativa. 
O documentário "Nunca fui, mas me disseram..." apresenta parte dessas distorções ao entrevistar moradores da Zona Sul da cidade do Rio de Janeiro a respeito de seus conhecimentos sobre a BF.

No início do documentário foi perguntado a 9 dos entrevistados se eles já foram a BF. Entre eles, somente 4 já tinham ido e desses, uma entrevistada tinha ido apenas uma vez. Quando perguntados sobre o nome de três municípios da referida região, apenas dois souberam citar. Entretanto, o que mais chama atenção são as distorções geográficas expressas na fala de alguns entrevistados. Os limites jurídicos dos lugares, independentemente da escala considerada, sempre foram um grande problema em relação à percepção das pessoas. Recorrentemente os entrevistados apresentaram dificuldades em definir os municípios que compõem a BF. Apenas dois conseguiram lembrar alguns dos 13 municípios da região. Os demais conseguiram destacar Nova Iguaçu e Duque de Caxias, os maiores municípios da Baixada Fluminense. Algumas vezes Nilópolis foi lembrada, mas quase sempre em razão do aspecto cultural emanado pela Escola de Samba Beija-Flor, sediada na cidade.

Essas confusões geográficas alimentam visões distorcidas em relação ao núcleo metropolitano e sua periferia baixadiana. Por vezes alguns entrevistados apontaram localidades cariocas das Zonas Norte e Oeste como integrantes da Baixada Fluminense, como os bairros Campo Grande, Santa Cruz, Del Castilho, Cascadura, Méier e Marechal Hermes (minuto 2). Para além do equívoco da distinção entre bairro e município, essa imprecisão não se deve apenas a proximidade geográfica desses espaços e sua distância geométrica em relação à Zona Sul carioca, mas, sobretudo, a semelhança socioeconômica entre esses bairros carioca e os municípios baixadianos.

Tal proximidade socioeconômica e espacial pode ter ajudado a criar no imaginário coletivo de moradores da ZS a ideia de região, pois para Gomes (2010, p. 53) a noção de região está condicionada "a um conjunto de área onde há o domínio de determinadas características que distingue aquela área das demais". A caracterização da região ao oscilar de acordo com os critérios adotados permite que a concepção dos limites geográficos no imaginário possam ser construídos pela mídia, considerando aspectos socioeconômicos e culturais para sua construção. Nesse sentido, os limites jurídico-formais são substituídos em prol de uma divisão pautada pelo conceito de "região homogênea". Assim sendo, para os moradores da ZS da urbe carioca, pode não existir diferença entre Anchieta e Nilópolis ou entre Campo Grande e Nova Iguaçu, por exemplo. Dessa forma, alguns bairros cariocas foram conurbados à Baixada Fluminense por meio da noção de violência, a qual Alves (2003) conceituou como baixadização de parte da Zona Norte.

A partir do minuto 5 do documentário começa-se a se discutir as notícias vinculadas a BF. Uma entrevistada, em tom irônico, diz que "notícia da Baixada é sempre assim: mataram dois, morreram três e um morreu de susto". A fala da entrevistada reforça ser a violência o elemento caracterizador dos municípios da Baixada Fluminense. A pseudo-homogeneidade da região é fruto da preguiça analítica dos meios midiáticos 
em não considerar as especificidades dos municípios que a constituem. A despeito da violência, as informações são noticiadas de modo a enfatizar sua ocorrência na Baixada Fluminense, como se essa fosse uma espécie de um ente federativo com $2.806 .489 \mathrm{~km}^{2}$.

Além de contribuir para o reforço da estigmatização da região como um todo, essa prática não cumpre o papel de informar de modo eficaz. Veicular a ocorrência de determinado ato de violência como acontecido na Baixada Fluminense somente, não esclarece o local do fato, comprometendo, assim a clareza geográfica da informação. Do mesmo modo que noticiar há existência de uma dinâmica imobiliária na Zona Oeste do Rio de Janeiro exige a especificação geográfica da ocorrência do fenômeno, pois um surto imobiliário na Barra da Tijuca apresentaria forma e conteúdo totalmente distinto de um localizado em Campo Grande, por exemplo. Dessa forma, informações sobre a Baixada Fluminense deveriam apresentar igual preocupação geográfica.

Por não ser essa a pratica comum, o imaginário coletivo da população fluminense e nacional consegue estipular com maior facilidade as distinções entre Barra da Tijuca e Campo Grande, mesmo sendo bairros de uma mesma área municipal, do que apontar diferenças socioeconômicas entre 13 municípios, como aqueles que constituem a Baixada Fluminense, os quais apresentam variações de toda ordem.

Para ilustrar essas discrepâncias, do ponto de vista demográfico, Duque de Caxias tem uma população residente de 855. 046, segundo o Censo Demográfico de 2010, enquanto Guapimirim tem apenas 51.483 habitantes. Segundo dados do IBGE para o ano de 2012, esses dois municípios também estavam nos extremos a despeito dos dados econômicos. Duque de Caxias detinha o maior PIB da Baixada Fluminense com 26.496.845 (em mil reais), enquanto o menor era o de Guapimirim com apenas 485.269 (em mil reais). Enquanto São João de Meriti apresenta impressionante densidade demográfica de 13.024,56 hab/km², em Guapimirim essa taxa era de $142 \mathrm{hab} / \mathrm{km}^{2}$. Esses dados expõem parte da distinção existente entre os municípios baixadianos.

Mesmo a violência, elemento amplamente considerado como caracterizador desse recorte espacial enquanto região, também apresenta consideráveis variações. Os 13 municípios abrangidos pela Baixada Fluminense compõem a 3ạ Regiões Integradas de Segurança Pública (RISP). Em uma escala geográfica menor, o Instituto de Segurança Pública (ISP) considera, ainda, as Áreas Integradas de Segurança Pública (AIPS), essas unidades geográficas são abrangidas pela área de atuação de cada batalhão de polícia militar e das circunscrições das delegacias da Polícia Civil e estão inseridas dentro das RISP. Nessa divisão territorial, os municípios da Baixada Fluminense encontram-se nas AIPS de número15 (Duque de Caxias), 20 (Nova Iguaçu, Mesquita e Nilópolis), 21 (São João de Meriti), 24 (Seropédica, Itaguaí, Japeri, Paracambi e Queimados), 34 (Magé e Guapimirim) e 39 (Belford Roxo). 
A metodologia de escala utilizada pelo ISP nos permite destrinchar a geografia da violência em unidades mais precisas que aquelas veiculadas nos meios midiáticos, os quais concebe toda a Baixada Fluminense como uma unidade territorial. Por meio dos dados divulgados pelas Delegacias de Polícia (DP) é possível extrair dados exclusivamente municipais de acordo com a área de atuação de cada DP. Para tanto somamos os números das 54ạ , 56ạ , 58ạ Delegacias Policiais, correspondente ao território de Duque de Caxias e as Delegacias 52ạ , 54ạ e 58ạa, as quais atuam em Nova Iguaçu. A tabela abaixo mostra os números absolutos relativos a vítimas de crimes violentos em cada município da região e sua ocorrência por grupo de 100 mil habitantes.

Tabela 2. vítimas de crimes violentos na 3a RISP (janeiro de 2015). Números absolutos e relativos por 100 mil habitantes. Fonte: Instituto de Segurança Pública, jan-2015. Modificado pelo autor.

\begin{tabular}{|c|c|c|c|c|c|c|c|c|}
\hline \multirow{2}{*}{ Municípios } & \multicolumn{2}{|c|}{ Homicídio doloso } & \multirow{2}{*}{$\begin{array}{c}\text { Lesão } \\
\text { Corporal } \\
\text { Seguida de } \\
\text { Morte }\end{array}$} & \multirow{2}{*}{$\begin{array}{l}\text { Latrocínio } \\
\text { (Roubo } \\
\text { seguido de } \\
\text { morte) }\end{array}$} & \multirow{2}{*}{$\begin{array}{c}\text { Tentativa de } \\
\text { Homicídio }\end{array}$} & \multicolumn{2}{|c|}{$\begin{array}{c}\text { Lesão Corporal } \\
\text { Dolosa }\end{array}$} & \multirow{2}{*}{ Estupro } \\
\hline & Absoluto & Relat. & & & & Absoluto & Relat. & \\
\hline D.de Caxias & 42 & 4.9 & 0 & 2 & 24 & 410 & 43.9 & 31 \\
\hline Novalguaçu & 38 & 4.7 & 0 & 1 & 21 & 379 & 47.6 & 42 \\
\hline Mesquita & 4 & 2.3 & 0 & 0 & 1 & 53 & 31.4 & 7 \\
\hline Nilópolis & 2 & 1.2 & 0 & 0 & 16 & 85 & 54.0 & 6 \\
\hline Seropédica & 4 & 5.1 & 0 & 0 & 1 & 40 & 51.1 & 3 \\
\hline Itaguaí & 3 & 2.7 & 0 & 0 & 12 & 61 & 55.9 & 7 \\
\hline Paracambi & 3 & 6.3 & 0 & 0 & 1 & 32 & 67.9 & 1 \\
\hline Queimados & 11 & 7.9 & 0 & 1 & 6 & 120 & 86.9 & 5 \\
\hline Japeri & 5 & 5.2 & 0 & 0 & 4 & 63 & 65.9 & 4 \\
\hline S.J.deMeriti & 20 & 4.3 & 0 & 0 & 13 & 272 & 59.3 & 15 \\
\hline Magé & 12 & 5.2 & 0 & 0 & 15 & 140 & 61.5 & 9 \\
\hline Guapimirim & 2 & 3.8 & 0 & 0 & 6 & 25 & 47.6 & 2 \\
\hline Bel. Roxo & 19 & 4.0 & 0 & 1 & 31 & 161 & 34.3 & 24 \\
\hline Baixada & 165 & & 0 & 5 & 151 & 1.882 & & 154 \\
\hline
\end{tabular}

Os dados expõem que a Baixada Fluminense totalizou 165 homicídios dolosos apenas em janeiro de 2015. O município de Guapimirim com 2 homicídios, correspondente a apenas 1,65\% desse total enquanto Duque de Caxias apresentou 42 homicídios (37\% do total da região). Entretanto, por ser integrante da mesma região, a percepção de violência para os agentes externos não estipula que o primeiro apresenta índices de violência muito inferior ao segundo, pois a veiculação midiática enfatiza a região como um todo. Do mesmo modo, das 151 tentativas de homicídios no período na Baixada Fluminense, Paracambi, Mesquita e Seropédica juntas respondem por apenas 3 casos, enquanto Nova Iguaçu sozinha responde por 21 casos. Levando-se em consideração a relação dos homicídios dolosos a cada grupo de 100 mil habitantes, Queimados apresenta uma taxa 6,5 vezes superior a Nilópolis, por exemplo.

A geografia imaginativa que se constrói da região se alicerça em preconceitos totalizantes, dessa forma, não importa se em Paracambi, por exemplo, houve um estupro em Janeiro de 2015, o destacado é que na Baixada Fluminense teve 154 estupros no período. Número assustador que corrobora com o estigma de 
"região perigosa" e que, por tabela insere Paracambi, Guapimirim e Seropédica nesse rol, conforme reportagem citada abaixo reproduzida pelo site de notícias $\mathrm{Uol}^{2}$.

Apesar de ter pouco mais da metade da população da cidade do Rio de Janeiro - 3,6 milhões de pessoas contra 6,3 milhões -, os 13 municípios que compõem a Baixada Fluminense registram juntos 59,1\% mais assassinatos que a capital, segundo dados do ISP (Instituto de Segurança Pública). Ao todo, foram cometidos cerca de cinco homicídios dolosos por dia na região em 2014, enquanto no Rio este número cai para cerca de três mortes por dia. Entre janeiro e outubro foram registrados 1.674 homicídios dolosos na Baixada Fluminense, que compreende os municípios de Duque de Caxias, Belford Roxo, Guapimirim, Itaguaí, Japeri, Magé, Mesquita, Nilópolis, Nova Iguaçu, Paracambi, Queimados, São João de Meriti, Seropédica. Já na cidade do Rio de Janeiro, no mesmo período, ocorreram 1.052 assassinatos.

Os dados socioeconômicos expostos brevemente acima nos apontam a importância de um debate em uma escala menor a fim de estabelecer diferenciações entre os municípios, fugindo de visões simplistas. Pesquisas macroescalares têm sua validade ao fomentar a criação de políticas públicas no âmbito dos governos estadual e federal. Nesse sentido, os dados municipais apresentariam relevância apenas em uma escala restrita. Ao defendermos a relevância e as pesquisas dos dados em âmbito municipal, não estamos propondo, a partir de sua tabulação, discutir a validade da Baixada Fluminense enquanto conceito geográfico de região, tampouco está se defendendo a inexistência da violência na região supracitada. Não queremos afirmar que os municípios menores demograficamente constituem-se em "paraísos" injustiçados pela mídia, o que pretendemos é mostrar que mesmo a violência não unifica a região, que nem toda a Baixada é um roteiro de filme de faroeste estadunidense. Existem especificidades que precisam ser respeitadas e estudadas. Tais exemplos corroboram para enfatizar que os municípios que integram a Baixada Fluminense não são homogêneos em diferentes aspectos. Podemos afirmar que a Baixada Fluminense são muitas do ponto de vista populacional, econômico, político, social e cultural.

Referindo-se a Baixada Fluminense no atual contexto, um entrevistado diz que "hoje em dia tá bem melhor do que 10, 15 anos atrás quando só havia violência" (minuto10). Apesar do reducionismo de entender a BF como somente território bárbaro, a fala do entrevistado expõe a alteração da percepção, ainda que tímida, da visão referente à Baixada Fluminense. Tal condição começa, em parte, a ser superada a partir dos anos 1990, quando a região iniciou um processo de transformação socioeconômico. Para Figueirêdo (2004) isso ocorreu porque

em decorrência do período econômico favorável houveram investimentos públicos direcionados para a área, com a expansão do sistema de transporte na abertura de rodovias no final da década de 20 do século XX, como as: Rodovia Washington Luiz, a antiga Rio - São Paulo, a Avenida Automóvel Club; expansão da rede elétrica; implantação do programa de saneamento da Baixada (elaborado pelo governo de Getúlio Vargas, em 1934) visando solucionar problemas que sempre a assolam, possibilitando desenvolvimento dos transportes e ocupação de terras; além da eletrificação da ferrovia ramal Central do Brasil - Japeri em 1938 até Nova Iguaçu, atingindo Japeri em 1943.

\footnotetext{
2 Disponível em http://noticias.uol.com.br/cotidiano/ultimas-noticias/2014/12/18/com-metade-da-populacao-baixada-fluminensetem-60-mais-homicidios-que-rio.htm (acesso em 19/03/15).
} 
Desse modo, a região passa por uma alteração em virtude das transformações ocorridas em alguns dos seus municípios. O dinamismo econômico verificado em Nova Iguaçu e Duque de Caxias - compreendido, também, na lógica do espraiamento da metrópole do Rio de Janeiro - possibilitou o aumento de arrecadação municipal favorecendo a melhoria da infraestrutura local. Além disso, o fortalecimento econômico arrefeceu, em certa medida, as migrações pendulares entre a Baixada Fluminense e o núcleo metropolitano e entre os municípios desta região. Quanto ao estereótipo de local violento, a região passa, a partir do início da década de 1990, a vivenciar o declínio dos grupos de extermínio e seus congêneres. A “espetacularização" da violência estendeu-se para o município do Rio de Janeiro com ênfase nas favelas das Zonas Norte e Oeste. Deslocaramse, assim, os "holofotes" midiáticos de violência, centrados até então na Baixada Fluminense, para os bairros cariocas.

A construção simbólica da Baixada Fluminense nos anos 1960, cristalizada no imaginário popular a partir dos grupos de extermínios (ALVES, 2003) e sob os axiomas de "região mais violenta do mundo" e de municípios atrasados do ponto de vista social, econômico, político e cultural precisou ser revista. Essa concepção, já redutora e carregada de estigmas naquela década, tornou-se, em certa medida, anacrônica e insuficiente para dar conta de uma análise que pretenda entender essa região no presente contexto. No aspecto econômico, municípios baixadianos como Duque de Caxias e Nova Iguaçu, por exemplo, estão entre os dez maiores Produto Interno Bruto (PIB) do estado. No aspecto social, em que pese as insuficiências analíticas do Índice de Desenvolvimento Humano (IDH), em nenhum município da Baixada Fluminense esse indicador é classificado como "baixo" - entre 0,500 e 0,599- ou "muito baixo"- entre 0 e 0,499. Dos 13 municípios da região, oito tiveram seu IDH classificado como "alto" - entre 0,700 e 0,799-, Nilópolis, Mesquita, Paracambi, São João de Meriti, Seropédica, Nova Iguaçu, Duque de Caxias e Magé, respectivamente.

Por conta dessas transformações, expressões como violência e miséria, palavras atreladas constantemente à região, esvaziaram-se, em parte, de significado, perderam força explicativas em si mesmas. As semânticas pejorativas referentes à Baixada Fluminense precisaram ser reformuladas e novas leituras, objetivando atualizar as análises desse recorte se impuseram. Neste cenário, discutir os novos percursos da Baixada Fluminense, mais que uma produção intelectual, se converteu em militância para os acadêmicos da região na perspectiva de estabelecer as distinções entre seus municípios componentes, para além de um mero olhar totalizante, mas um olhar que busque apontar suas especificidades.

A visão reducionista sobre a BF é amplamente empreendida pelos veículos midiáticos. Essa prática é apontada pelos próprios entrevistados, os quais entendem que a mídia cria verdades, manipula e produz um discurso de carência em relação à Baixada Fluminense (minuto 9). Contudo, os próprios reforçam os estereótipos associados à região ao produzir frases como "Eles não se incomodam muito com o lugar sujo"; 
"Eles comem qualquer coisa"; "Tudo o que eles usam eles têm um lugarzinho pra colocar, mas eles não colocam, não, eles vão jogando onde eles estão" (minuto 18).

A criação no imaginário dos moradores da ZS sobre os "nativos" da BF, como expresso na fala da entrevistada, aparece eivada de estereótipos. A construção dessa narrativa, na acepção de Albuquerque Júnior (2012, p. 13) caracteriza-se como

\begin{abstract}
um discurso assertivo, imperativo, repetitivo, caricatural. É uma fala arrogante, de quem se considera superior ou está em posição de hegemonia, uma voz segura e autossuficiente que se arroga no direito de dizer o que o outro é em poucas palavras. O estereótipo nasce de uma caracterização grosseira, rápida e indiscriminada de um grupo estranho; esse é dito em poucas palavras, é reduzido a poucas qualidades que são ditas como essenciais. O estereótipo é uma espécie de esboço rápido e negativo do que é o outro. Uma fala redutiva e reducionista, em que as diferenças e multiplicidades presentes no outro são apagadas em nome da fabricação de uma unidade superficial, de uma semelhança sem profundidade. O estereótipo pretende dizer a verdade do outro em poucas linhas e desenhar seu perfil em poucos traços, retirando dele qualquer complexidade, qualquer dissonância, qualquer contradição. O estereótipo lê o outro sempre de uma maneira, de uma forma simplificadora e acrítica, levando a uma imagem e uma verdade do outro que não é passível de discussão ou problematização. 0 estereótipo constitui e institui uma forma de ver e dizer o outro que dá origem justamente a práticas que o confirmam ou que o veiculam, tornando-o realidade, à medida que é incorporado, subjetivado.
\end{abstract}

Outras falas refletem a geografia imaginativa dos entrevistados. Ainda no minuto 18 , falando sobre suas percepções, a entrevistada imagina que "Lá deve ter casa e casa com quintal, deve ter pé de manga"; "A galera deve se divertir bem mais"; "As pessoas são mais alegres devido à infelicidade do desnível social"; "Não têm tantas ambições". Quanto à dimensão espacial das residências, as casas da Baixada Fluminense, em sua maioria possui quintal. Contudo, esse ganho espacial em seu habitat comprometeu em grande medida o direito à cidade de seus moradores. Isso porque a maior parte dos municípios da Baixada Fluminense teve sua origem em loteamentos. O fracionamento das terras que antes cumpriam uma função agrícola e sua conversão para uso residencial, se inscreveu na estratégia do setor imobiliário de auferir maiores lucros. Para Pacheco (1984, p. 17),

\begin{abstract}
este setor favoreceu o crescimento descontínuo do espaço metropolitano, na medida em que reservou terrenos mais próximos às áreas centrais como o intuito de esperar sua valorização, ao passo que áreas longínquas, além dos limites do então Distrito Federal, foram oferecidas à população de baixa renda, sem a necessária infra-estrutura urbana. É desse modo que desponta e se institucionaliza a periferia como habitat dessas populações pobres: atendendo aos interesses imobiliários.
\end{abstract}

Por essa estratégia territorial, as amenidades da cidade e os benefícios da proximidade geográfica com o centro da cidade, foram reservados as populações de maior status social. Na periferia, em terrenos mais baratos e por isso mesmo mais amplos, se instalou a população mais pobre. Em razão disso, é preciso lembrar os percalços de se morar em áreas periféricas, sobretudo para os trabalhadores, pois essa região "reflete com maior crueza as desigualdades desencadeadas a partir do núcleo metropolitano" (PACHECO, 1984, p. 19), de tal sorte que morar em uma favela da Zona Sul carioca apresenta conotação diferente de residir em um 
"aglomerado subnormal" da Baixada Fluminense, tanto no que se refere ao acesso aos postos de trabalho, quanto no acesso ao consumo de bens e serviços.

Tanto assim que uma entrevista se sente a vontade para caracterizar a BF como local no qual "a rua é cheio de buracos", onde "não tem esgoto, não tem água, as crianças cheias de dengue" (minuto 17), mesmo sendo ela moradora da favela da Rocinha. Essa favela, apenas por questões geográficas está inserida na Zona Sul carioca, mas por uma análise socioeconômica poderia muito bem ser mais um município da Baixada Fluminense, pois as carências apontadas em sua fala como caracterizadora dos municípios baixadianos, estão em larga medida presentes em seu local de moradia. Nesse caso, são as vantagens provenientes da localização geográfica da Rocinha que garantiriam sua "superioridade" em relação a BF e não necessariamente sua infraestrutura.

Assim, "o território metropolitano fluminense se caracteriza, portanto, pela nítida proleção das linhas de divisão da sociedade fluminense, de tal forma que morar em um lugar ou outro da metrópole não é indiferente" (RIBEIRO et al., 2013, p.171) . Por esta pesperctiva, Saramago (2015, p. 135) lembra que "para poder chegar aonde se quer, tudo depende de onde se esteja", dessa forma, morar na BF não determina a condição social futura de sua população, mas, inequivocamente, impõe consideráveis entraves a ascensão social, pois

\begin{abstract}
pessoas com as mesmas virtualidades, a mesma formação, até mesmo o mesmo salário têm valor segundo o lugar em que vivem: as oportunidades não são as mesmas. Por isso, a possibilidade de ser mais, ou menos, cidadão depende, em larga proporção, do ponto do território onde se está. Enquanto um lugar vem a ser condição de sua pobreza, um outro lugar poderia, no mesmo momento histórico, facilitar o acesso àqueles bens e serviços que lhe são teoricamente devidos, mas que, de fato, Ihes falta (SANTOS, 2014, p. 107).
\end{abstract}

As restrições impostas a essas populações, as quais eventualmente podem comprometer sua ascensão social, passam a ser interpretadas como "falta de ambição" para as pessoas de renda mais elevada e a alegria, entendida como uma consequência do desnível social, como argumenta uma entrevistada, sugere no fundo mais uma estratégia de defesa para amenizar a angústia oriunda da disparidade social e não necessariamente uma covardia frente ao desnível econômico da RMRJ.

No minuto 20 a entrevistada diz que nunca foi à Baixada Fluminense e que isso não deveria ser entendido como um preconceito. Para defender seu raciocínio, a mesma diz que também nunca foi a Disneylândia. O fato de não ter ido a um determinado local não explica, necessariamente, a não ida a outro. A distância entre a Baixada Fluminense e a Zona Sul carioca é de apenas $45 \mathrm{~km}$ enquanto a distância geográfica entre a ZS e a cidade de Orlando nos Estados Unidos, onde ficam os parques temáticos é de cerca de 7.000 km, fato que impossibilita qualquer comparativo geométrico espacial entre os espaços. Contudo, na construção simbólica, o desejo de consumir o espaço da BF e da Disneylândia ocupa lugares destoantes. O 
fetiche é altamente distinto. Isso nos impele a asseverar que se o parque de diversões estivesse na mesma distância espacial que a BF, a entrevistada provavelmente já o teria visitado. Se o argumento apresentado pela entrevistada fosse tomado como correto, ele pode servir para escamotear preconceitos em relação a qualquer lugar do mundo visto que sempre vai existir algum lugar no qual nunca fomos.

Quando perguntados se existiriam mundos diferentes ao referi-se a Zona Sul e a Baixada Fluminense, dois entrevistados disseram concordar com a afirmação. Para diferenciar os dois espaços, usaram expressões como "aqui as pessoas são mais educadas"; "mais refinadas"; "hábito diferentes, modo de se vestir diferente, lazer diferente". Um entrevistado ainda insinua a existência de um "raciocínio diferente" (minuto 25). Uma entrevistada advoga que tais distinções seriam fruto de uma "diferenciação regional". Apesar das inúmeras possibilidades analíticas abrigadas pelo conceito de região, a hipótese de nossos dois recortes territoriais apresentarem diferenças culturais marcantes entre si como sugere a fala da entrevistada, é altamente questionável.

Seria tarefa árdua sustentar a tese da existência de modelos de vidas distintos em localidades tão próximas e nas quais há um fluxo intenso de capital, de pessoas, de serviços e de informações orientada, sobretudo, pela malha de integração de transporte. Dessa maneira, a eventual "deselegância discreta" das meninas da Baixada Fluminense talvez seja fruto não de um gosto duvidoso, mas da impossibilidade de comprar roupas na mesma loja que a "moça do corpo dourado do sol de Ipanema" pode comprar.

As distinções apontadas pelos entrevistados não se deve, assim, a um modo de vida diferente. As populações da BF e da ZS são submetidas aos mesmos dilemas, padecem, em graus distintos, de mesma insegurança que assola as maiores regiões metropolitanas do país. O diferencial existente entre ambas se deve a natureza do consumo, as condições financeiras. Por essa razão, o consumo cultural é condicionado não tanto pelo refinamento do consumidor, mas pelas possibilidades financeiras de cada um para sua aquisição.

Na Baixada Fluminense certamente há pessoas que gostam de Woody Allen, como alerta um morador da ZS (minuto 33), contudo consumir uma cerveja em um bar e fazer o churrasco com os amigos no quintal, conforme lembrou uma entrevistada, é mais barato e menos dispendioso do que ver um festival do diretor estadunidense em um cinema da Zona Sul, por exemplo. Por outro lado, na ZS o acesso a muitos equipamentos culturais pode ser realizado a pé e as opções de lazer gratuito são mais numerosas.

No contexto fluminense a praia é por excelência um local de encontro dos desiguais: do playboy, como pejorativamente são chamados os moradores de maior renda da ZS e dos "farofeiros", como pejorativamente são chamados os moradores mais pobres do subúrbio carioca e da BF. Mesmo esse local democrático quanto ao acesso, não é necessariamente gratuito para as pessoas que moram longe do litoral. Um morador de Nilópolis, por exemplo, que queira ir à praia de Copacabana usando transporte público, tem duas opções. Pode 
ir de trem e depois tomar um ônibus ou ainda um ônibus e depois o metrô. Na primeira opção o valor gasto no trajeto de ida e volta é de $\mathrm{R} \$ 16,40$, na segunda opção $\mathrm{R} \$ 16,30$. Considerando uma família composta por quatro pessoas, somente os gastos de transporte para usufruir de espaço público como a praia corresponderia a $\mathrm{R} \$ 65,60$, ou aproximadamente $8 \%$ do salário mínimo vigente.

Parte dessa disparidade no acesso aos bens culturais pode ser explicada pela desigualdade de renda entre os moradores da metrópole fluminense, outra parte, essa ainda mais substancial, se deve as ineficientes políticas culturais públicas. A análise espacial dos equipamentos culturais mantidos pelo governo do Estado do Rio de Janeiro indica claramente a geografia desigual da prestação desse tipo de serviços voltados ao lazer considerando o estado como um todo e o interior da RMRJ, conforme aponta os equipamentos ofertados (Quadro 1).

Quadro 1. Equipamentos públicos geridos pela Funarj de acordo com a localização no Estado do Rio de Janeiro. Fonte: www.funarj.gov.br

\begin{tabular}{|c|c|}
\hline Espaço Cultural & Localização \\
\hline Casa da Marquesa- Museu da Moda Brasileira & Rio de Janeiro- São Cristóvão \\
\hline Casa de Casimiro de Abreu & Casimiro de Abreu \\
\hline Casa de Cultura Laura Alvim & Rio de Janeiro- Ipanema \\
\hline Casa de Euclides da Cunha & Cantagalo \\
\hline Casa de Oliveira Viana & Niterói \\
\hline Casa Rio & Rio de Janeiro- Botafogo \\
\hline Escola de Música Villa-Lobos & Rio de Janeiro- Centro \\
\hline Gabinete de Leitura Guilherme Araújo & Rio de Janeiro- Ipanema \\
\hline Museu Antônio Parreiras & Niterói \\
\hline Museu Carmen Miranda & Rio de Janeiro- Flamengo \\
\hline Museu do Ingá & Niterói \\
\hline Sala Cecília Meireles & Rio de Janeiro- Lapa \\
\hline Teatro Armando Gonzaga & Rio de Janeiro- Marechal Hermes \\
\hline Teatro Arthur Azevedo & Rio de Janeiro- Campo Grande \\
\hline Teatro Glaucio Gill & Rio de Janeiro- Copacabana \\
\hline Teatro João Caetano & Rio de Janeiro- Centro \\
\hline Teatro Mário Lago & Rio de Janeiro- Bangu \\
\hline Teatro Villa-Lobos & Rio de Janeiro- Copacabana \\
\hline
\end{tabular}

A Fundação Anita Mantuano de Artes do Estado do Rio de Janeiro (FUNARJ) é uma autarquia responsável pela gestão de alguns espaços públicos do governo do estado. A essa fundação compete à gestão de 18 equipamentos públicos entre centro culturais, museus e teatros. Desse total de equipamentos, apenas 2 estão localizados no interior do Estado, um no município de Casimiro de Abreu (Baixadas Litorâneas) e outro em Cantagalo (Região Serrana). Dentre os 16 equipamentos culturais localizados na RMRJ, 13 estão na cidade do Rio de Janeiro e os outros três restantes no município de Niterói. 
A Baixada Fluminense mesmo sendo composta por 13 municípios com uma população superior a 3 milhões de habitantes, não conta atualmente com nenhum equipamento cultural do governo estadual. Em contrapartida, a ZS, nosso outro recorte espacial, com uma população 5 vezes menor que a BF é contemplada com 6 espaços culturais. Já passamos da hora de "construir a linha vermelha da cultura" (minuto 32), como insiste um entrevistado em referencia a via rodoviária que liga a BF a ZS. Dessa forma, a diferença social da qual o rendimento mensal per capita informa no comparativo entre as duas regiões analisadas, explicaria apenas uma divisão social entre seus moradores. A diferenciação no tocante ao consumo desses bens culturais se relaciona, também, com uma escolha política. Com efeito, a presença de espaços culturais privados próximos a população de renda mais elevada se explica pela lógica do mercado, já a concentração desses mesmos espaços culturais de gestão pública nessa área de renda mais elevada não encontra nenhuma explicação do ponto de vista social que objetive a construção de um Estado menos desigual. Pelo contrário, o Estado não atua no sentido de minimizar as disparidades, mas as acirra quando dota algumas áreas de equipamentos culturais em detrimento de outras áreas.

As notícias da Baixada Fluminense aparecem frequentemente nas páginas criminais dos jornais, poucas vezes sua produção frequenta o caderno de cultura. Como reflexo dessa predileção jornalística, quando perguntados sobre referências culturais na Baixada Fluminense foram lembrados o grupo musical Cidade Negra, surgido em Belford Roxo, o sambista Neguinho da Beija-Flor, nascido em Nova Iguaçu mas projetado nacionalmente por ser interprete da Escola de Samba Beija-Flor de Nilópolis, além da Agremiação Carnavalesca Grande Rio, de Duque de Caxias. Essas foram as únicas referências genuínas da Baixada Fluminense lembradas pelos entrevistados. As demais referências citadas foram o sambista Zeca Pagodinho, que embora seja associado a Xerém (distrito de Duque de Caxias) em razão de ser proprietário de um sítio na localidade, nasceu em Irajá, bairro da Zona Norte do Rio de Janeiro. Outros ícones culturais baixadianos erroneamente citados pelos moradores da Zona Sul foram os jogadores de futebol Ronaldo (nascido no bairro de Bento Ribeiro, Zona Norte), Romário (nascido no bairro de Olaria, Zona Norte) e Ronaldinho Gaúcho, o qual o adjetivo já indica sua origem.

As percepções dos moradores da ZS não autorizam concluir a existência de dois mundos conforme o senso comum faz crer, mas de apenas duas localidades com distintas características socioeconômicas, como lembra a professora Luciana Corrêa do Lago, moradora do bairro do Leblon e uma das entrevistadas do documentário. A entrevistada aponta ainda que a existência de heterogeneidade social mesmo no Leblon, entretanto ela é invisibilizada em prol do lado mais "novelesco" do bairro. Do mesmo modo e respeitada às devidas proporções, essa constatação se aplica a Baixada Fluminense. Existe população de elevado status social em Nova Iguaçu (Caonze) e Duque de Caxias (25 de agosto), indicando um processo similar de heterogeneidade social na Baixada Fluminense. Contudo, como as exceções parecem não ter existência, do 
mesmo modo que a população de rendimento mais baixo é invisível no Leblon, a população de elevado status social da Baixada Fluminense não aparece nos noticiários.

Dessa maneira, podem até existir dois mundos, mas não entre a BF e a ZS e sim dentro dessas áreas. A disparidade de renda não ocorre somente a partir da contraposição das duas, mas também, em seu interior. Há um descompasso em relação às possibilidades de acesso a produtos culturais específicos, mas isso diz respeito ao consumo somente e não a essência cultural em si. Pode-se consumir produtos culturais diferentes, mas isso isoladamente não atesta a existência de uma cultura distinta. Com efeito, pode-se ouvir música clássica na BF, pode-se ouvir pagode na ZS, pois o gosto pessoal atende a critérios muito mais subjetivos que os limites jurídicos- geográficos delimitados pelo legislador possam suspeitar e o preconceito social, comum a parte da elite econômica, pretenda impor.

\section{CONSIDERAÇÕES FINAIS}

O espaço é simultaneamente imaginário e material e devido a essa condição, toda construção imaginativa (ideologia) é capaz de produzir materialidade. Com efeito, a visão que se tem de um determinado espaço passa, necessariamente, por uma construção simbólica, a qual geralmente tende a preceder sua observação material. Essa constatação pode ser considerada a partir dos dois recortes espaciais selecionados neste artigo, pois a visão simbólica referente à BF impede, em larga medida, que os moradores da Zona Sul a frequentem. Nesse sentido, a restrição relativa ao fluxo de pessoas em determinados espaços se converte em um dado real. Em razão disso, essa construção simbólica, a priori imaterial, é capaz de produzir materialidades.

Toda construção espacial é antecipada por sua construção imaginária. Antes de conhecer empiricamente um local, criamos expectativas em relação a ele mediadas por conhecimentos prévios das mais distintas naturezas. Este artigo ambicionou apontar que essas expectativas e visões parecem diametralmente opostas para a BF e a ZS. Enquanto a primeira aparece sempre atrelada a atraso socioeconômico, violência e carências, a segunda é sinônimo de paisagens bonitas e harmonização social.

Nós, moradores da BF, não objetivamos desmentir por completo o imaginário social amplamente aceito. Sabidamente a BF apresenta carências de múltiplas naturezas e nesse sentido, nos cabe, também, denunciar essas mazelas. Contudo, as críticas tecidas neste artigo em relação às opiniões de alguns moradores da Zona Sul, não devem ser entendidas como a de uma mãe latina, a qual fala mal do seu filho, mas não permite que outros falem. Críticas devem ser feitas, desde que com argumentos sólidos e, preferencialmente, embasadas empiricamente.

A empiria permite superar a geografia imaginativa, pois, como lembra um fragmento da música Tendo a Lua do grupo Os Paralamas do Sucesso: "o céu de Ícaro tem mais poesia que o de Galileu". Segundo a 
Mitologia Grega, Ícaro quis conhecer o céu e para tanto criou asas de cera. À medida que ele as agitava e subia ao firmamento, as asas aqueciam e, mais próximas ao sol, derretiam. Ícaro se machucava a cada tentativa. Já Galileu, astrônomo italiano, observava os fenômenos celestes no conforto e segurança que a distância possibilita com instrumentos telescópicos. Assim sendo, tentar compreender as nuances da Baixada Fluminense à distância a partir dos noticiários e "do nunca fui, mas me disseram", embora garanta a segurança de Galileu, jamais vai permitir alcançar a poesia de Ícaro.

\section{REFERÊNCIAS}

ALBUQUERQUE JÚNIOR, Durval Muniz. Preconceito contra a origem geográfica e de lugar: as fronteiras da discórdia. São Paulo: Edições MMM, 2012.

ALVES, José Cláudio Souza. Dos Barões ao Extermínio: Uma História da Violência na Baixada Fluminense. Duque da Caxias, RJ: APPHCLIO, 2003.

BELOCH, Israel. Capa preta e Lurdinha: Tenório Cavalcanti e o povo da Baixada. Rio de Janeiro: Record, 1986.

BOURDIEU, Pierre. Economia das trocas lingüísticas. São Paulo: EDUSP, 1996.

CAPEL, Horacio. La Morfologia de lãs Ciudades I. Sociedade, Cultura y Paisaje Urbano. Barcelona: Editora del Serbal, 2002.

CARDOSO, Elizabeth Dezouzart. Estrutura Urbana e Representações: a invenção da Zona Sul e a construção um novo processo de segregação espacial no Rio de Janeiro nas primeiras décadas do século XX. VIII Seminário de História da Cidade e do Urbanismo (UFF), Niterói, em 2004.

COSTA, Amanda Danelli. História e Cultura Urbana Carioca: a natureza turística do Rio de Janeiro entre a cidade das letras e a cidade maravilhosa. In: Turismo e Território no Brasil e na Itália: novas perspectivas, novos desafios. EdUERJ, 2014. pp. 123-161

DRIVER, F .Imaginative Geographies. In: CLOKE, P.; CRANG, P.; GOODWIN, M. (orgs.). Introducing Human Geographies. London: Arnold, 2005.

FIGUERÊDO, Maria Aparecida de. Gênese e (re) produção do espaço brasileiro na Baixada Fluminense. In: Revista Geo-Paisagem on line - ano 3, no 5. Rio de Janeiro, RJ, 2004.

FOUCAULT, Michel. A Ordem do Discurso. São Paulo: Loyola, 1996.

GEIGER, Pedro Pinchas; SANTOS, Ruth Lyra. Notas Sobre a Evolução da Ocupação Humana da Baixada Fluminense. Rio de Janeiro: IBGE, 1956. Separata da Revista Brasileira de Geografia. Rio de Janeiro, no 3- Ano XVI. jul/set. 1955.

GÓES, Hildebrando de Araújo. Relatório apresentado pelo engenheiro chefe da Comissão de Saneamento da Baixada Fluminense. Rio de Janeiro: s/ editor, 1934.

GOMES, Paulo Cesar da Costa. O Conceito de Região e sua Discussão. In: Castro, Iná Elias de, Gomes, Paulo César da Costa, Corrêa, Roberto Lobato (orgs). Geografia: conceitos e temas. Rio de Janeiro: Bertrand Brasil, 2010.p 49-73.

JOLY, Martine. Introdução a Análise da Imagem. 11 ed. Campinas: Papirus, 2007.

LAGO, Luciana Corrêa do. Desigualdades e Segregação na Metrópole: o Rio de Janeiro em Tempo de Crise. Rio de Janeiro: Revan, 2000 .

MAGALHÃES, Alex Lamonica. et al. Alma (naque)... da Baixada. Rio de Janeiro: APPH-CLIO, 2013. 
MORAES, Antonio Carlos Robert. Ideologias Geográficas. São Paulo: Hucitec, 1996.

MORAN, José Manuel. Educar o Educador. Campinas, 2009. Disponível em: www.eca.usp.br/prof/moran/educar.htm.

OLIVEIRA, Rafael da Silva (org). Baixada Fluminense: Novos estudos e desafios. [s.l]: Paradigma Editora, 2004.

PACHECO, Susana Mara Miranda. Produção e Reprodução de Loteamentos na Periferia do Rio de Janeiro. 1984, 218p. Tese (Doutorado). Instituto de Geociências- Universidade Federal do Rio de Janeiro, Rio de Janeiro, 1984.

PIRES, Hindenburgo Francisco. Planejamento e intervenções urbanísticas no Rio de Janeiro: a utopia do plano estratégico e sua inspiração catalã. Biblio 3W - Revista Bibliográfica de Geografía y Ciencias Sociales. Barcelona: Universidad de Barcelona, Vol. XV, no 895 (13), 5 de noviembre de 2010.

RIBEIRO, Luiz César Queiroz et al. Território e Trabalho: segregação e segmentação urbanas e oportunidades ocupacionais na Região Metropolitana do Rio de Janeiro. In: SANTOS, Angela Moulin S. Penalva; MARAFON, Gláucio José; SANT'ANNA, Maria Josefina Gabriel. Rio de Janeiro: Um olhar Socioespacial. Rio de Janeiro: Grama, 2013.

RIBEIRO, Miguel Angelo; O’ NEILL, Maria Mônica Vieira Caetano. Considerações sobre a dinâmica populacional fluminense: contrastes entre a metrópole e o interior. In: MARAFON, G. J RIBEIRO, M. A., (orgs). Revisitando o território fluminense IV. Rio de Janeiro: Gramma, 2012.

SANTOS, Angela Moulin Simões Penalva. Economia Fluminense: Superando a Perda do Dinamismo? Disponível em : www2.uerj.br/IPP, 2002.

SANTOS, Milton. Metamorfoses do Espaço Habitado. $6^{\circ}$ ed. São Paulo: Edusp, 2012.

O Espaço do Cidadão. $7^{\circ}$ ed. São Paulo: Edusp, 2014.

SARAMAGO, José. Ensaio sobre a cegueira. São Paulo: Companhia das Letras, 2015.

SEGATAS SOARES, Maria Therezinha de. Nova Iguaçu: absorção de uma célula urbana pelo grande Rio de Janeiro. In: Revista brasileira de Geografia. Rio de Janeiro, Ano 24, № 2, pp.157-241, Abr-jun. 1962.

SIMÕES, Manoel Ricardo. A Cidade Estilhaçada: Reestruturação Econômica e Emancipações Municipais na Baixada Fluminense. 1 ed. Mesquita-RJ: Entorno, 2008.

SOUZA, Marlucia Santos de. Escavando o Passado da Cidade: História política da Cidade de Duque de Caxias. Duque de Caxias/RJ: APPH-CLIO, 2014. 